\title{
WYDŁUŻANIE TRWANIA ŻYCIA A PŁATNOŚCI RENTOWE Z UBEZPIECZEŃ OC
}

Anna Jędrzychowska dr, Katedra Ubezpieczeń, Uniwersytet Ekonomiczny we Wrocławiu

\author{
Ilona Kwiecień \\ dr hab., Katedra Ubezpieczeń, \\ Uniwersytet Ekonomiczny we Wrocławiu \\ Patrycja Kowalczyk-Rólczyńska \\ dr, Katedra Ubezpieczeń, \\ Uniwersytet Ekonomiczny we Wrocławiu
}

\section{Wprowadzenie}

Obserwowane w ostatnich latach starzenie się ludności w krajach europejskich, jest nie tylko konsekwencją zmniejszenia dzietności, ale także zjawiska wydłużania się trwania życia, Pozytywne skądinąd z punktu widzenia jednostki, stanowi istotną implikację dla gospodarki oraz rynku finansowego, prowadząc dyskusję naukową nad ryzykiem długowieczności (longevity) w obszarze finansów, w tym ubezpieczeń ${ }^{1}$.

Ryzyko to postrzegane jest $\mathrm{w}$ ujęciu negatywnym ${ }^{2}$ na poziomie indywidualnym, jako ryzyko przeżycia dłużej niż nagromadzone bogactwo oraz zagregowanym, jako ryzyko, że przeciętny członek grupy urodzeniowej będzie żyć dłużej niż oczekiwano [MacMinn i in. 2006: 551].

Tak dłuższe trwanie życia, jak zwiększający się udział osób starszych w społeczeństwie jest istotnym wyzwaniem tak dla państw, jak i instytucji finansowych, głównie banków, zakładów ubezpieczeń oraz funduszy hipotecznych. Podmioty te będą musiały uwzględniać wydłużanie się trwania życia w zarządzaniu systemami emerytalnymi oraz portfelem oferowanych produktów, w szczególności tych, które narażone są właśnie na ryzyko długowieczności z uwagi na płatności okresowe bez zakreślenia

1 M.in. Trzpiot [2015a], Trzpiot [2015b], MacMinn i in. [2006]; Ngai i Sherris [2011].

2 Które implikuje potrzebę zarządzania ryzykiem. 
horyzontu czasowego. Przy niektórych produktach, jak odwrócona hipoteka czy renty z zamkniętym okresem płatności ryzyko właściwej oceny okresu wypłaty ciążyć będzie na beneficjencie.

W artykule autorki wskazują dane obrazujące zjawisko wydłużania trwania życia oraz ilustrują problem wpływu zjawiska w obszarze ubezpieczeń poprzez weryfikację znaczenia tego czynnika w kształtowaniu płatności rentowych w ubezpieczeniach OC. Z uwagi na ograniczone ramy ilustracja zawężona została do dwóch zagadnień - wpływu wydłużania się dalszego trwania życia na obecną wartość kapitału rentowego oraz tego, jak przy utrzymaniu stałej wysokości minimalnej sumy gwarancyjnej obniża się wysokość kapitału na poczet miesięcznego świadczenia.

\section{Zjawisko wydłużania trwania życia}

Analiza danych demograficznych opublikowanych przez Eurostat [http://ec.europa.eu/eurostat/data/database] pozwala na oczywistą konstatację, że mamy do czynienia $\mathrm{z}$ wydłużaniem się trwania życia. W roku 1960 przeciętne trwanie życia w Polsce wynosiło 67,7 lat, natomiast w 2014 roku 77,8 lat. W wielu krajach europejskich sytuacja była podobna ${ }^{3}$. Proces ten będzie postępował w kolejnych latach, bowiem jak przewiduje Komisja Europejska (2015) w krajach będących członkami Unii Europejskiej przeciętne trwanie życia wzrośnie o nieco ponad 7 lat dla mężczyzn oraz 6 lat w przypadku kobiet w roku $2060 \mathrm{w}$ porównaniu do roku 2013. Według prognoz Eurostatu, wydłużanie się trwania życia będzie najszybciej postępowało $\mathrm{w}$ krajach rozwijających się. $\mathrm{Z}$ danych dotyczących prognozy przeciętnego trwania życia $w$ wybranych krajach europejskich zaprezentowanych na rysunku 1 , wynika, że największy przyrost trwania życia w grupie mężczyzn w latach 2015-2080, będzie miał miejsce na Litwie (15,4 lat), w Bułgarii (13,3 lat) oraz w Polsce (12,4 lat). Natomiast w krajach rozwiniętych przyrost ten będzie na niższym poziomie tj. we Włoszech 7,5 lat, Wielkiej Brytanii 8 lat oraz Niemczech 8,4 lat. Trwanie życia kobiet wydłuży się o mniejszą liczę lat, choć i tak w krajach rozwijających się w stosunku do krajów rozwiniętych proces ten będzie szybszy (w Bułgarii 10,8 lat, a we Włoszech 6,6 lat).

3 Dla przykładu: w Niemczech przeciętne trwanie życia w roku 1960 wynosiło 69,6 lat, a w 2014 roku 81,2 lata; w Wielkiej Brytanii w roku 1960 odnotowano przeciętne trwanie życia na poziomie 71,1 lat a w 2014 roku było to już 81,4 lat. 

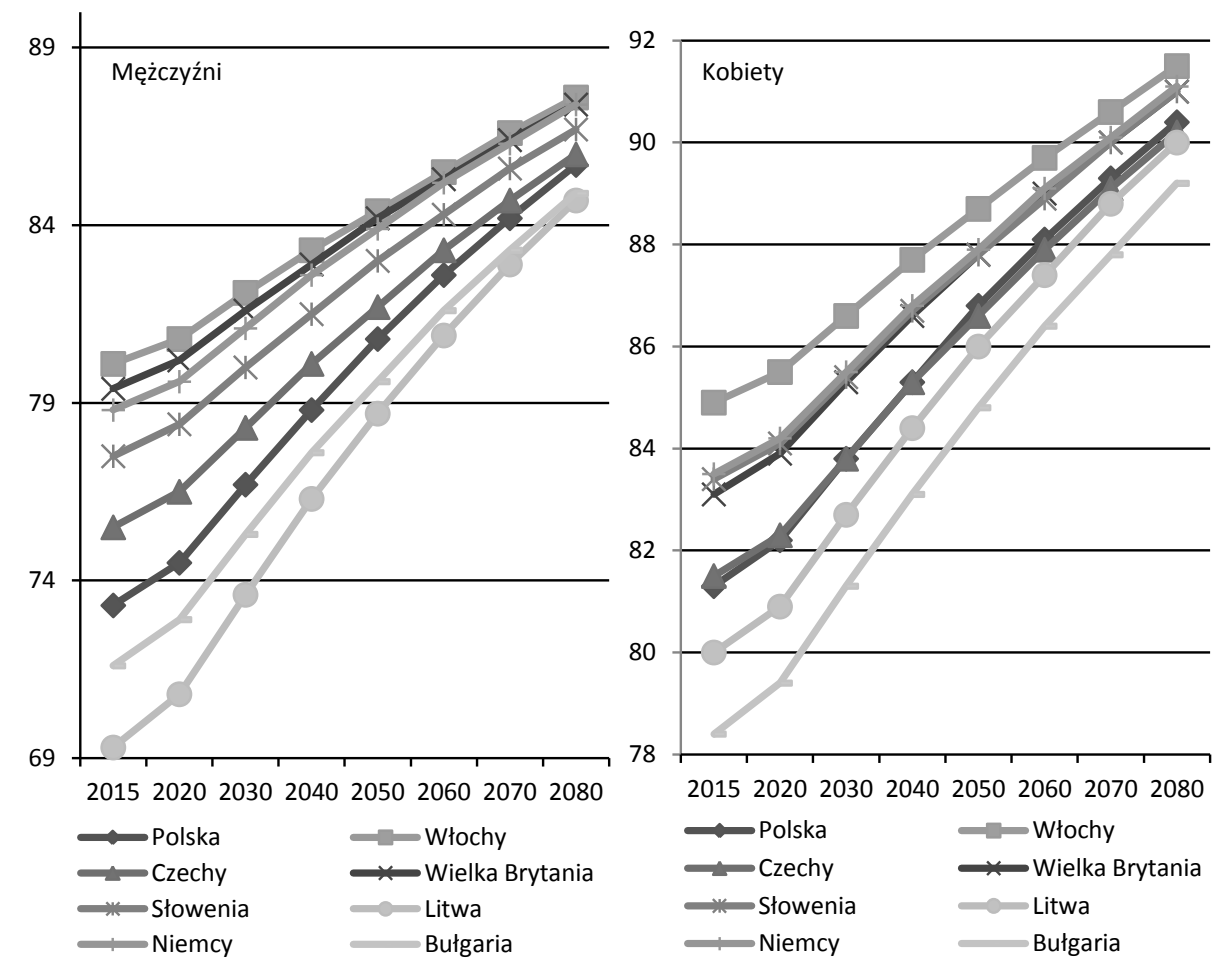

Rysunek 1. Przeciętne trwanie życia dla mężczyzn i kobiet w latach 2015-2080 w wybranych krajach europejskich (2015 - dane rzeczywiste, 2020-2080 - prognoza)

Żródło: opracowanie własne na podstawie danych z Eurostatu [http://ec.europa.eu/eurostat/ data/database]

Starzenie się populacji, nie tylko w Europie, ale na całym świecie, uzależnione jest od poziomu rozwoju społeczno-gospodarczego. Im wyższy poziom rozwoju, tym wyższa jakość życia, niższa dzietność oraz dłuższe trwanie życia, a w konsekwencji wyższy udział osób starszych ${ }^{4} \mathrm{w}$ populacji [szerzej: Jurek 2012]. Na rysunku 2 zaprezentowano prognozę liczby ludności w Polsce do roku 2050, z której wynika, że istotnie będzie wzrastała liczba osób starszych $(60+)$ w społeczeństwie, a malała zarówno liczba dzieci, jak i liczba osób w wieku produkcyjnym. Zjawisko to rodzi wiele obaw, bowiem krótszy czas przeobrażeń demograficznych w Polsce (i innych krajach rozwijających się), w stosunku do krajów już rozwiniętych, spowodować może brak stosownego przygotowania się m.in. niedostosowania infrastruktury zapewniającej bezpieczeństwo socjalne osobom starszym.

$4 \quad$ W literaturze przedmiotu za metrykalny próg starości przyjmuje się wiek 60 lat lub 65 lat. 


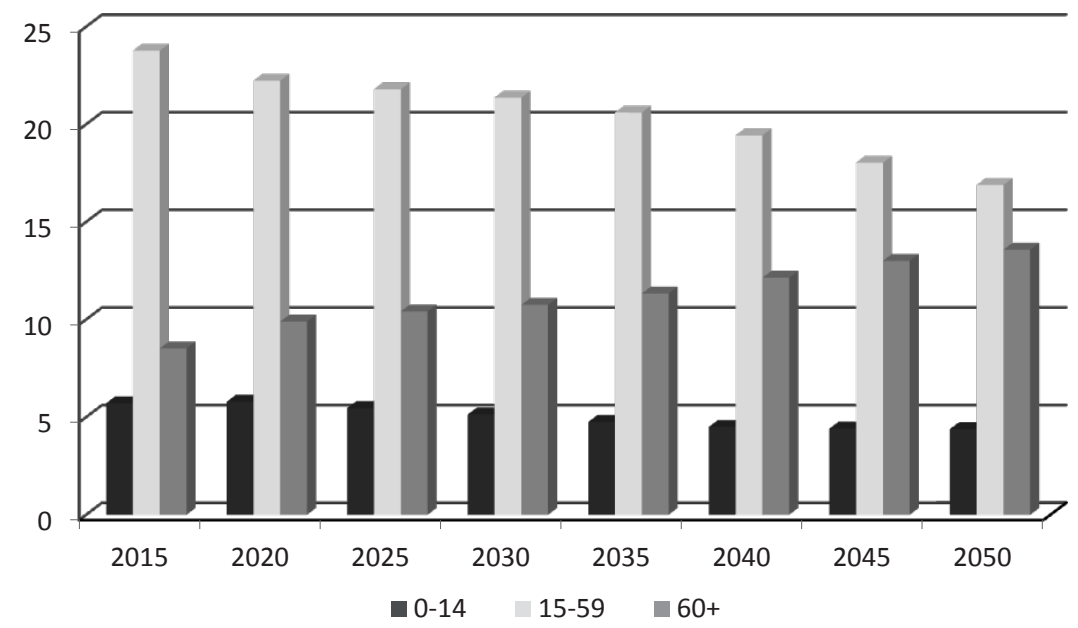

Rysunek 2. Liczba ludności w Polsce w podziale na grupy wiekowe w latach 2015-2050 (w mln osób; 2015 - dane rzeczywiste, 2020-2050 - prognoza)

Źródło: opracowanie własne na podstawie danych z GUS (www.stat.gov.pl).

Identyfikowane na tle powyższych analiz ryzyko dotyczy zarówno jednostek, jak i całych roczników demograficznych. Indywidualne (specyficzne) ryzyko długowieczności (specific longevity risk), polega na tym, że dana osoba dożyje dłuższego wieku niż oczekiwała. Na ten rodzaj ryzyka będą narażone głównie osoby, które korzystają z części uzupełniającej systemu emerytalnego (np. wypłata świadczeń z ubezpieczeń na życie i dożycie, z odwróconego kredytu hipotecznego). Natomiast ryzyko długowieczności dotyczące całych roczników demograficznych, nazywane zagregowanym ryzykiem długowieczności (aggregate longevity risk), polega na tym, że średnia długość życia dla danego rocznika będzie dłuższa niż przewidywano. Z ryzykiem długowieczności związane jest ryzyko zmian w przebiegu śmiertelności. Może ono powodować - $\mathrm{w}$ przypadku niekorzystnych zmian w przebiegu śmiertelności polegających na np. wcześniejszych zgonach spowodowanych chorobami cywilizacyjnymi - niedoszacowanie wartości wypłacanego świadczenia i wówczas ryzyko to ponosi osoba pobierająca świadczenie. Natomiast w przypadku korzystnych zmian przebiegu śmiertelności, polegających na omawianym tutaj wydłużaniu się życia, ryzyko to realizowało się będzie poprzez przeszacowanie wartości wypłacanego świadczenia i wówczas ryzyko to ponosi instytucja wypłacająca świadczenie. Na ten rodzaj ryzyka długowieczności narażone są głównie te instytucje, które wypłacają świadczenia dożywotnio. Łącznie specyficzne ryzyko długowieczności i zagregowane ryzyko długowieczności stanowią tzw. całkowite ryzyko długowieczności (total longevity risk) [Blake i in. 2010]. 


\section{Płatności rentowe z ubezpieczeń OC}

Przedmiotem kompensacji $\mathrm{w}$ świadczeniach $\mathrm{w}$ postaci rent $\mathrm{z}$ ubezpieczeń OC, co do zasady są straty majątkowe, dotyczące dochodów uzyskiwanych cyklicznie lub wydatków ponoszonych cyklicznie. Kompensacja tego rodzaju strat następuje w systemach prawnych w dwóch formułach ${ }^{5}$ :

- w postaci ryczałtowej kwoty (lump sum) - założeniem tu jest zazwyczaj, że kwota ta wystarczy na zakup hipotetycznej renty przez okres oddziaływania szkody,

- w postaci płatności okresowej, zazwyczaj miesięcznej.

W polskim systemie prawa cywilnego zasadą jest kompensacja w postaci renty (świadczeń okresowych), która może obejmować:

a) utracone zarobki - dla poszkodowanego bezpośrednio, który w konsekwencji doznanego uszkodzenia ciała lub rozstroju zdrowia stracił całkowicie lub częściowo zdolność do pracy zarobkowej albo zmniejszyły się jego widoki na przyszłość (art. $444 \$ 2$ k.c.);

b) zwiększone koszty utrzymania - dla poszkodowanego bezpośrednio, którego potrzeby zwiększyły się w konsekwencji doznanego uszkodzenia ciała lub rozstroju (art. $444 \$ 2$ k.c.);

Sąd Najwyższy wskazuje, że mamy tu $(\mathrm{a}, \mathrm{b})$ trzy odrębne rodzaje renty: $\mathrm{z}$ tytułu utraty zdolności do zarobkowania, $\mathrm{z}$ tytułu zwiększenia się potrzeb poszkodowanego oraz z tytułu zmniejszenia się jego widoków powodzenia na przyszłość; każda $\mathrm{z}$ wymienionych w tym przepisie podstaw świadczenia rentowego stanowi samoistną przesłankę jego zasądzenia ${ }^{6}$;

c) utracone środki utrzymania - dla poszkodowanego pośrednio, który pozbawiony został świadczeń alimentacyjnych w konsekwencji śmierci poszkodowanego bezpośrednio (art. $446 \S 2$ k.c.); renta ta określana rentą alimentacyjną przyznawana jest obligatoryjne (przy spełnieniu przesłanek zawartych w kodeksie rodzinnym i opiekuńczym) w przypadku osób, względem, których ciążył na zmarłym ustawowy obowiązek alimentacyjny, bądź fakultatywne - jeżeli z okoliczności wynika, że wymagają tego zasady współżycia społecznego - wobec innych osób bliskich, którym zmarły dobrowolnie i stale dostarczał środków utrzymania ${ }^{7}$.

5 Przegląd rozwiązań systemowych w zakresie szkód o charakterze majątkowym, wynikających ze szkody na osobie [w:] Kwiecień i Jędrzychowska [2013], por. także Ward [2009].

6 Wyrok SN z dnia 14 września 2009 r. [II PK 65/09, LEX nr 558304].

$7 \quad$ Z jednej strony nie jest tu konieczna bliska więź czy pokrewieństwo ze zmarłym, $z$ drugiej jednak strony konieczną przesłanką jest fakt dostarczania przez zmarłe- 
W odniesieniu do rent dla bezpośrednio poszkodowanego płatności w przypadku trwałego uszczerbku na zdrowiu przybierać będą formę płatności długookresowej, płatnej do końca życia - bezspornie w zakresie renty na zwiększone potrzeby. W odniesieniu do utraty dochodów, spotyka się rozbieżne stanowiska, co do płatności w okresie po momencie, w którym zwyczajowo dochodzi do ustania aktywności zawodowej. Jednak kwestia ta nie jest oczywista, bowiem z jednej strony podejście o płatności do okresu przejścia w stan spoczynku wymagałoby kompensowania $\mathrm{w}$ rencie utraconych oszczędności emerytalnych, z drugiej coraz powszechniejsza jest aktywność zawodowa na emeryturze, choćby w zmniejszonym wymiarze.

Renta alimentacyjna przyznawana jest na okres, przez jaki przysługiwałyby środki utrzymania od zmarłego. W przypadku małżonka może być nieograniczony - do jego śmierci gdy ze względu na stan zdrowia, wiek lub inne ważne okoliczności (np. zamieszkiwanie na terenie o wysokim stopniu bezrobocia) nie jest jej w stanie podjąć.

Odejściem od reguły płatności okresowych świadczeń z odpowiedzialności cywilnej jest możliwość w polskim systemie ustalenia wypłaty świadczenia rentowego w formie jednorazowej płatności (tzw. renty skapitalizowanej). Warunkiem są jednak ważne powody, tak by leżało to w interesie poszkodowanego (por. art. 447 k.c.) $)^{8}$. Ustalenie wysokości renty wypłaconej jednorazowo bazuje na wartości obecnej świadczenia, które gdyby zostało utrzymane w formie podstawowej, było by strumieniem przyszłych wypłat.

\section{Znaczenie wydłużania trwania życia w płatnościach rentowych - ilustracje kalkulacyjne}

W tej części artykułu zostaną zilustrowane dwa zagadnienia: wzrost wartości obecnej kapitału potrzebnego do pokrycia roszczenia rentowego oraz zmniejszanie się puli środków na miesięczne świadczenia przy zachowaniu stałej sumy gwarancyjnej.

go pomocy materialnej stale, nie wystarczy zatem jednorazowe czy sporadyczne wsparcie. Nie jest także wymogiem fakt, by pomoc ta stanowiła jedyne źródło utrzymania osoby dochodzącej renty; por. Szpunar [2000: 114].

8 Szczegółowo na temat problemów ekonomicznych w odniesieniu do rent z ubezpieczeń OC por. Kwiecień i Jędrzychowska [2014]. 
W obu wariantach zostanie obliczona renta terminowa dla osoby 30-letniej, w dwóch wariantach:

1. Renty stałej $P V=A \cdot q \frac{q^{n}-1}{q-1} \cdot \frac{1}{q^{n}}$

2. Renty indeksowanej (rosnącej) $P V=A \cdot q \frac{q^{n}-d^{n}}{q-d} \cdot \frac{1}{q^{n}}$

gdzie:

$A$ - wysokość świadczenia (w obu przypadkach miesięcznego),

$q=1+r$, gdzie $r$ to stopa dyskontowa,

$d=1+i$, gdzie $i$ to stopa indeksacji,

$n$ - liczba miesięcy życia (zgodnie z prognozowaną długością trwania życia).

Założono, że skoro renty są świadczeniem o długim horyzoncie, to można oprzeć się na wartościach średnich. Dlatego za wskaźnik indeksacji rent przyjęto średnią wartość inflacji w krajach UE za lata 2004-2014. Zaś za stopę dyskontową przyjęto oprocentowanie 10-letnich obligacji skarbowych w krajach UE, jest to średnio 2,5\%.

Dla każdego $\mathrm{z}$ analizowanych państw przyjęto prognozy długości trwanie życia dla obywateli zgodnie z rokiem ich urodzenia. Do analizy wybrano roczniki: 2015, 2030, 2060 i 2080. Dane pochodzą z Eurostatu. Podobnie dane nt. wysokości średniego wynagrodzenia netto w poszczególnych krajach i wskaźnik inflacji dla krajów UE przyjęto z Eurostatu. Zaś informację na temat oprocentowania 10-letnich obligacji skarbowych - z banku centralnego.

W pierwszej sprawdzono jaki wpływ na obecną wartość kapitału rentowego ma wydłużanie się dalszego trwania życia obywateli. Przyjęto założenie, że renta przyznana jest w wysokości odpowiadającej wielkości przeciętnego wynagrodzenia w gospodarce (wg Eurostatu).

Obecna wartość rent ma znaczenie dla świadczeniodawcy (np. zakładu ubezpieczeń), który winien znać obecny rozmiar swoje zobowiązania, by móc utworzyć rezerwę kapitałową na jego poczet. Ale także dla samego poszkodowanego, ponieważ nierzadko praktykuje się wystąpienie o wypłatę jednorazową tego świadczenia.

Otrzymane wyniki (tab. 1) pokazują dwie rzeczy. Pierwsza z nich, dość intuicyjna, pokazuje, że najwyższe wartości obecnych wartości rent ustalone zostały dla krajów o wysokim stopniu rozwoju gospodarki (Wielka Brytania, Niemcy i Włochy), zaś najniższe dla słabiej rozwiniętych (Bułgaria, Litwa i Rumunia). Oczywiście ma to związek z oparciem wyników o wartość przeciętnych wynagrodzeń w gospodarce. 


\begin{tabular}{|c|c|c|c|c|c|c|c|c|c|c|}
\hline & \multicolumn{4}{|c|}{ PV renty } & \multicolumn{3}{|c|}{ Różnica kwotowo do 2015} & \multicolumn{3}{|c|}{ Różnica procentowo do 2015} \\
\hline & 2015 & 2030 & 2060 & 2080 & $2030-2015$ & 2060-2015 & 2080-2015 & \% 2015 & \% 2015 & \% 2015 \\
\hline \multicolumn{11}{|c|}{ Płatności stałe - 30-letni mężczyzna } \\
\hline Bułgaria & 103731,78 & 108726,14 & 116355,97 & 119831,78 & 4994,36 & 12624,20 & 16100,00 & $104,81 \%$ & $112,17 \%$ & $115,52 \%$ \\
\hline Czechy & 238322,16 & 246080,58 & 258515,15 & 264545,24 & 7758,41 & 20192,98 & 26223,08 & $103,26 \%$ & $108,47 \%$ & $111,00 \%$ \\
\hline Litwa & 173867,08 & 184617,14 & 200219,49 & 207407,07 & 10750,05 & 26352,40 & 33539,98 & $106,18 \%$ & $115,16 \%$ & $119,29 \%$ \\
\hline Niemcy & 789014,70 & 807896,95 & 838432,80 & 853427,69 & 18882,25 & 49418,11 & 64412,99 & $102,39 \%$ & $106,26 \%$ & $108,16 \%$ \\
\hline Polska & 202794,10 & 211359,95 & 224586,83 & 230750,82 & 8565,85 & 21792,73 & 27956,72 & $104,22 \%$ & $110,75 \%$ & $113,79 \%$ \\
\hline Rumunia & 120280,75 & 126178,60 & 134979,28 & 139185,52 & 5897,85 & 14698,53 & 18904,77 & $104,90 \%$ & $112,22 \%$ & $115,72 \%$ \\
\hline Słowacja & 212004,94 & 220805,32 & 234566,02 & 241246,45 & 8800,37 & 22561,08 & 29241,51 & $104,15 \%$ & $110,64 \%$ & $113,79 \%$ \\
\hline Wielka Bryt. & 963594,77 & 985402,45 & 1018444,41 & 1035927,65 & 21807,67 & 54849,64 & 72332,87 & $102,26 \%$ & $105,69 \%$ & $107,51 \%$ \\
\hline Włochy & 599881,20 & 611673,25 & 630077,55 & 641253,16 & 11792,04 & 30196,34 & 41371,96 & $101,97 \%$ & $105,03 \%$ & $106,90 \%$ \\
\hline \multicolumn{11}{|c|}{ Płatności stałe - 30-letnia kobieta } \\
\hline Bułgaria & 112589,74 & 115983,46 & 121344,30 & 124052,86 & 3393,72 & 8754,57 & 11463,12 & $103,01 \%$ & $107,78 \%$ & $110,18 \%$ \\
\hline Czechy & 254133,03 & 259676,24 & 268640,57 & 273371,53 & 5543,21 & 14507,54 & 19238,50 & $102,18 \%$ & $105,71 \%$ & $107,57 \%$ \\
\hline Litwa & 198397,55 & 203741,95 & 212020,66 & 216209,51 & 5344,40 & 13623,11 & 17811,97 & $102,69 \%$ & $106,87 \%$ & $108,98 \%$ \\
\hline Niemcy & 825722,03 & 840204,20 & 864966,74 & 877557,88 & 14482,17 & 39244,71 & 51835,85 & $101,75 \%$ & $104,75 \%$ & $106,28 \%$ \\
\hline Polska & 222129,36 & 226974,50 & 234809,93 & 238945,11 & 4845,14 & 12680,56 & 16815,74 & $102,18 \%$ & $105,71 \%$ & $107,57 \%$ \\
\hline Rumunia & 130750,89 & 134764,88 & 140922,98 & 143945,91 & 4013,99 & 10172,09 & 13195,01 & $103,07 \%$ & $107,78 \%$ & $110,09 \%$ \\
\hline Słowacja & 229877,37 & 235655,86 & 245043,29 & 249733,17 & 5778,49 & 15165,92 & 19855,80 & $102,51 \%$ & $106,60 \%$ & $108,64 \%$ \\
\hline Włochy & 999282,14 & 1018444,41 & 1048626,21 & 1063972,92 & 19162,28 & 49344,07 & 64690,78 & $101,92 \%$ & $104,94 \%$ & $106,47 \%$ \\
\hline Wielka Bryt. & 626965,16 & 636169,42 & 651449,53 & 659618,31 & 9204,26 & 24484,37 & 32653,14 & $101,47 \%$ & $103,91 \%$ & $105,21 \%$ \\
\hline \multicolumn{11}{|c|}{ Płatności rosnące - 30-letni mężczyzna } \\
\hline Bułgaria & 124044,63 & 131739,19 & 144088,35 & 149991,63 & 7694,56 & 20043,72 & 25947,00 & $106,20 \%$ & $116,16 \%$ & $120,92 \%$ \\
\hline Czechy & 288935,60 & 301303,05 & 321906,65 & 332289,79 & 12367,46 & 32971,06 & 43354,19 & $104,28 \%$ & $111,41 \%$ & $115,00 \%$ \\
\hline Litwa & 206136,22 & 222370,55 & 247316,60 & 259467,58 & 16234,33 & 41180,38 & 53331,36 & $107,88 \%$ & $119,98 \%$ & $125,87 \%$ \\
\hline Niemcy & 967737,30 & 998776,02 & 1050589,74 & 1076842,03 & 31038,72 & 82852,44 & 109104,73 & $103,21 \%$ & $108,56 \%$ & $111,27 \%$ \\
\hline Polska & 243972,59 & 257373,96 & 279042,88 & 289607,87 & 13401,37 & 35070,29 & 45635,28 & $105,49 \%$ & $114,37 \%$ & $118,71 \%$ \\
\hline Rumunia & 143877,91 & 152975,66 & 167243,50 & 174405,01 & 9097,75 & 23365,59 & 30527,10 & $106,32 \%$ & $116,24 \%$ & $121,22 \%$ \\
\hline Słowacja & 254900,92 & 268640,82 & 291119,32 & 302536,19 & 13739,91 & 36218,40 & 47635,27 & $105,39 \%$ & $114,21 \%$ & $118,69 \%$ \\
\hline Wielka Bryt. & 1184222,51 & 1220264,01 & 1276496,06 & 1307117,69 & 36041,49 & 92273,55 & 122895,18 & $103,04 \%$ & $107,79 \%$ & $110,38 \%$ \\
\hline Włochy & 739114,57 & 758725,17 & 790151,55 & 809765,98 & 19610,60 & 51036,99 & 70651,41 & $102,65 \%$ & $106,91 \%$ & $109,56 \%$ \\
\hline \multicolumn{11}{|c|}{ Płatności rosnące - 30-letnia kobieta } \\
\hline Bułgaria & 137895,34 & 143466,73 & 152622,27 & 157435,32 & 5571,40 & 14726,94 & 19539,98 & $104,04 \%$ & $110,68 \%$ & $114,17 \%$ \\
\hline Czechy & 314527,74 & 323884,71 & 339504,53 & 348016,93 & 9356,97 & 24976,78 & 33489,19 & $102,97 \%$ & $107,94 \%$ & $110,65 \%$ \\
\hline Litwa & 244307,78 & 253213,64 & 267524,43 & 275033,20 & 8905,87 & 23216,65 & 30725,42 & $103,65 \%$ & $109,50 \%$ & $112,58 \%$ \\
\hline Niemcy & 1028765,21 & 1053661,82 & 1097442,09 & 1120343,35 & 24896,61 & 68676,87 & 91578,13 & $102,42 \%$ & $106,68 \%$ & $108,90 \%$ \\
\hline Polska & 274918,41 & 283097,02 & 296749,80 & 304 190,21 & 8178,62 & 21831,39 & 29271,81 & $102,97 \%$ & $107,94 \%$ & $110,65 \%$ \\
\hline Rumunia & 160276,07 & 166884,84 & 177436,92 & 182824,25 & 6608,78 & 17160,85 & 22548,18 & $104,12 \%$ & $110,71 \%$ & $114,07 \%$ \\
\hline Słowacja & 283312,25 & 292957,60 & 309191,88 & 317595,34 & 9645,35 & 25879,63 & 34283,09 & $103,40 \%$ & $109,13 \%$ & $112,10 \%$ \\
\hline Wielka Bryt. & 1243636,00 & 1276496,06 & 1329769,18 & 1357636,12 & 32860,06 & 86133,18 & 114000,11 & $102,64 \%$ & $106,93 \%$ & $109,17 \%$ \\
\hline Włochy & 784762,82 & 800790,98 & 828044,27 & 842970,10 & 16028,17 & 43281,45 & 58207,28 & $102,04 \%$ & $105,52 \%$ & $107,42 \%$ \\
\hline
\end{tabular}

Tabela 1. Wartości obecne rent dla poszczególnych lat urodzenia (w euro)

Żródło: opracowanie własne na podstawie danych z Eurostatu [http://ec.europa.eu/eurostat/ data/database] oraz banku Centralnego [http://data.worldbank.org]. 


\begin{tabular}{|c|c|c|c|c|c|c|c|c|c|c|}
\hline & \multicolumn{4}{|c|}{ PV renty } & \multicolumn{3}{|c|}{ Różnica kwotowo do 2015} & \multicolumn{3}{|c|}{ Różnica procentowo do 2015} \\
\hline & 2015 & 2030 & 2060 & 2080 & 2030-2015 & $2060-2015$ & 2080-2015 & \% 2015 & $\% 2015$ & \% 2015 \\
\hline \multicolumn{11}{|c|}{ Płatności stałe - 30-letni mężczyzna } \\
\hline Bułgaria & 15994,78 & 15260,05 & 14259,40 & 13845,80 & $-734,73$ & $-1735,38$ & $-2148,98$ & $95,41 \%$ & $89,15 \%$ & $86,56 \%$ \\
\hline Czechy & 15229,74 & 14749,56 & 14040,12 & 13720,07 & $-480,18$ & $-1189,62$ & $-1509,67$ & $96,85 \%$ & $92,19 \%$ & $90,09 \%$ \\
\hline Litwa & 16540,41 & 15577,27 & 14363,40 & 13865,63 & $-963,14$ & $-2177,01$ & $-2674,78$ & $94,18 \%$ & $86,84 \%$ & $83,83 \%$ \\
\hline Niemcy & 14671,25 & 14328,35 & 13806,50 & 13563,92 & $-342,90$ & $-864,75$ & $-1107,33$ & $97,66 \%$ & $94,11 \%$ & $92,45 \%$ \\
\hline Polska & 15643,95 & 15009,94 & 14125,92 & 13748,58 & $-634,01$ & $-1518,03$ & $-1895,37$ & $95,95 \%$ & $90,30 \%$ & $87,88 \%$ \\
\hline Rumunia & 15976,52 & 15229,72 & 14236,74 & 13806,51 & $-746,80$ & $-1739,78$ & $-2170,01$ & $95,33 \%$ & $89,11 \%$ & $86,42 \%$ \\
\hline Słowacja & 15677,70 & 15052,85 & 14169,77 & 13777,40 & $-624,85$ & $-1507,93$ & $-1900,30$ & $96,01 \%$ & $90,38 \%$ & $87,88 \%$ \\
\hline Wielka Bryt. & 14582,12 & 14259,40 & 13796,78 & 13563,93 & $-322,72$ & $-785,34$ & $-1018,19$ & $97,79 \%$ & $94,61 \%$ & $93,02 \%$ \\
\hline Włochy & 14470,92 & 14191,95 & 13777,40 & 13537,28 & $-278,97$ & $-693,52$ & $-933,64$ & $98,07 \%$ & $95,21 \%$ & $93,55 \%$ \\
\hline \multicolumn{11}{|c|}{ Płatności stałe - 30-letnia kobieta } \\
\hline Bułgaria & 14736,41 & 14305,19 & 13673,21 & 13374,68 & $-431,22$ & $-1063,20$ & $-1361,73$ & $97,07 \%$ & $92,79 \%$ & $90,76 \%$ \\
\hline Czechy & 14282,23 & 13977,34 & 13510,93 & 13277,11 & $-304,89$ & $-771,30$ & $-1005,12$ & $97,87 \%$ & $94,60 \%$ & $92,96 \%$ \\
\hline Litwa & 14495,31 & 14115,08 & 13563,92 & 13301,14 & $-380,23$ & $-931,39$ & $-1194,17$ & $97,38 \%$ & $93,57 \%$ & $91,76 \%$ \\
\hline Niemcy & 14019,06 & 13777,40 & 13382,97 & 13190,96 & $-241,66$ & $-636,09$ & $-828,10$ & $98,28 \%$ & $95,46 \%$ & $94,09 \%$ \\
\hline Polska & 14282,22 & 13977,33 & 13510,90 & 13277,11 & $-304,89$ & $-771,32$ & $-1005,11$ & $97,87 \%$ & $94,60 \%$ & $92,96 \%$ \\
\hline Rumunia & 14697,17 & 14259,39 & 13636,29 & 13349,92 & $-437,78$ & $-1060,88$ & $-1347,25$ & $97,02 \%$ & $92,78 \%$ & $90,83 \%$ \\
\hline Słowacja & 14458,80 & 14104,25 & 13563,92 & 13309,19 & $-354,55$ & $-894,88$ & $-1149,61$ & $97,55 \%$ & $93,81 \%$ & $92,05 \%$ \\
\hline Włochy & 13845,80 & 13645,46 & 13325,41 & 13160,38 & $-200,34$ & $-520,39$ & $-685,42$ & $98,55 \%$ & $96,24 \%$ & $95,05 \%$ \\
\hline Wielka Bryt. & 14061,36 & 13796,78 & 13399,67 & 13206,40 & $-264,58$ & $-661,69$ & $-854,96$ & $98,12 \%$ & $95,29 \%$ & $93,92 \%$ \\
\hline \multicolumn{11}{|c|}{ Płatności rosnące - 30-letni mężczyzna } \\
\hline Bułgaria & 13375,57 & 12594,33 & 11514,91 & 11061,73 & $-781,24$ & $-1860,66$ & $-2313,84$ & $94,16 \%$ & $86,09 \%$ & $82,70 \%$ \\
\hline Czechy & 12561,91 & 12046,28 & 11275,27 & 10922,95 & $-515,63$ & $-1286,64$ & $-1638,96$ & $95,90 \%$ & $89,76 \%$ & $86,95 \%$ \\
\hline Litwa & 13951,13 & 12932,62 & 11628,13 & 11083,59 & $-1018,51$ & $-2323,00$ & $-2867,54$ & $92,70 \%$ & $83,35 \%$ & $79,45 \%$ \\
\hline Niemcy & 11961,74 & 11590,01 & 11018,41 & 10749,80 & $-371,73$ & $-943,33$ & $-1211,94$ & $96,89 \%$ & $92,11 \%$ & $89,87 \%$ \\
\hline Polska & 13003,51 & 12326,42 & 11369,21 & 10954,47 & $-677,09$ & $-1634,30$ & $-2049,04$ & $94,79 \%$ & $87,43 \%$ & $84,24 \%$ \\
\hline Rumunia & 13356,24 & 12561,91 & 11409,23 & 11018,40 & $-794,33$ & $-1947,01$ & $-2337,84$ & $94,05 \%$ & $85,42 \%$ & $82,50 \%$ \\
\hline Słowacja & 13039,37 & 12372,47 & 11417,14 & 10986,28 & $-666,90$ & $-1622,23$ & $-2053,09$ & $94,89 \%$ & $87,56 \%$ & $84,25 \%$ \\
\hline Wielka Bryt. & 11865,38 & 11514,93 & 11007,67 & 10749,79 & $-350,45$ & $-857,71$ & $-1115,59$ & $97,05 \%$ & $92,77 \%$ & $90,60 \%$ \\
\hline Włochy & 11744,92 & 11441,34 & 10986,27 & 10720,18 & $-303,58$ & $-758,65$ & $-1024,74$ & $97,42 \%$ & $93,54 \%$ & $91,28 \%$ \\
\hline \multicolumn{11}{|c|}{ Płatności rosnące - 30-letnia kobieta } \\
\hline Bułgaria & 12032,07 & 11564,82 & 10871,07 & 10538,71 & $-467,25$ & $-1161,00$ & $-1493,36$ & $96,12 \%$ & $90,35 \%$ & $87,59 \%$ \\
\hline Czechy & 11539,80 & 11206,41 & 10690,82 & 10429,33 & $-333,39$ & $-848,98$ & $-1110,47$ & $97,11 \%$ & $92,64 \%$ & $90,38 \%$ \\
\hline Litwa & 11771,35 & 11357,34 & 10749,79 & 10456,30 & $-414,01$ & $-1021,56$ & $-1315,05$ & $96,48 \%$ & $91,32 \%$ & $88,83 \%$ \\
\hline Niemcy & 11252,17 & 10986,29 & 10548,01 & 10332,39 & $-265,88$ & $-704,16$ & $-919,78$ & $97,64 \%$ & $93,74 \%$ & $91,83 \%$ \\
\hline Polska & 11539,80 & 11206,41 & 10693,82 & 10429,33 & $-333,39$ & $-845,98$ & $-1110,47$ & $97,11 \%$ & $92,67 \%$ & $90,38 \%$ \\
\hline Rumunia & 11989,74 & 11514,93 & 10830,13 & 10511,01 & $-474,81$ & $-1159,61$ & $-1478,73$ & $96,04 \%$ & $90,33 \%$ & $87,67 \%$ \\
\hline Słowacja & 11731,76 & 11345,49 & 10749,80 & 10465,35 & $-386,27$ & $-981,96$ & $-1266,41$ & $96,71 \%$ & $91,63 \%$ & $89,21 \%$ \\
\hline Wielka Bryt. & 11298,53 & 11007,66 & 10566,67 & 10349,79 & $-290,87$ & $-731,86$ & $-948,74$ & $97,43 \%$ & $93,52 \%$ & $91,60 \%$ \\
\hline Włochy & 11061,74 & 10840,32 & 10483,54 & 10297,91 & $-221,42$ & $-578,20$ & $-763,83$ & $98,00 \%$ & $94,77 \%$ & $93,09 \%$ \\
\hline
\end{tabular}

Tabela 2. Wysokość miesięcznego świadczenia, które można wypłacić z minimalnej sumy gwarancyjnej ubezpieczenia OC posiadaczy pojazdów mechanicznych 30-letniemu poszkodowanemu (w euro) Żródło: opracowanie własne na podstawie danych z Eurostatu [http://ec.europa.eu/eurostat/ data/database] oraz banku Centralnego [http://data.worldbank.org]. 
Druga rzecz pokazuje przełożenie się faktu wydłużania się życia na wartość obecną rent. Odniesiono wartości obecne rent policzone dla osoby 30-letniej urodzonej w roku 2030, 2060 i 2080 do wartości obecnej renty, która byłaby ustalona dla osoby urodzonej w roku 2015. Te wyniki pokazują, że kapitał potrzebny na wypłatę renty wzrasta znacząco w krajach, w których obserwuje się największe wydłużanie się życia. I tak dla przykładu wartość obecna renty stała dla mężczyzny urodzonego w Niemczech w 2080 r. jest o 8\% wyższa niż dla urodzonego w 2015 r., ale w Bułgarii i Rumuni różnica ta to już 15\%, a na Litwie 19\%. W przypadku renty rosnącej dla mężczyzny: w Niemczech jest to $11 \%$, w Rumuni $21 \%$, w Bułgarii 21\%, na Litwie 26\%.

Warto zwrócić tez uwagę, że wartości obecne rent w Polsce to rząd kilkunastu procent. Odpowiednia renta stała: dla mężczyzny to wzrost o 14\%, dla kobiety o $8 \%$; renta rosnąca: dla mężczyzny wzrost o $19 \%$, dla kobiety $11 \%$.

Drugie poruszone $\mathrm{w}$ artykule zagadnienie to pokazanie tego, jak przy utrzymaniu stałej wysokości minimalnej sumy gwarancyjnej - dla przykładu z najpowszechniejszego ubezpieczenia obowiązkowego posiadaczy pojazdów mechanicznych przyjęto 5 mln Euro - obniża się wysokość kapitału na poczet miesięcznego świadczenia. Świadczenie miesięczne może pokrywać utracone dochody i zwiększone potrzeby poszkodowanego, a nawet kilku poszkodowanych jeśli z polisy wypłacane jest świadczenie kilku osobom.

Wyniki (tab. 2 oraz rys. 3) wskazują, że wartości kapitału do dyspozycji dla osób urodzonych w późniejszych latach, a zatem żyjących dłużej, jeśli minimalne sumy gwarancyjne nie zostaną zwiększone będą niższe niż otrzymują obecnie poszkodowani. Ponownie największe skutki zdarzeń demograficznych widać w obniżeniu wartości kapitału w Bułgarii, Rumunii i na Litwie. Pula środków na stałe świadczenie miesięczne dla mężczyzny w Rumunii urodzonego w 2080 r. to 86\% środków dla osoby urodzonej w 2015 r. Przy rencie zmiennej to obniżenie do 82\%.

\section{Podsumowanie}

Przedstawiona analiza prowadzi do wniosków, że w istocie mamy do czynienia ze zjawiskiem wydłużania się trwania życia, które będzie wymuszało wiele zmian $\mathrm{w}$ zasadzie na wszystkich płaszczyznach funkcjonowania rynku, w tym zabezpieczenia społecznego i finansowego. Rodzi to istotne wyzwania dla instytucji finansowych, które będą zmuszone do aktywnego zarządzania ryzykiem długowieczności. 

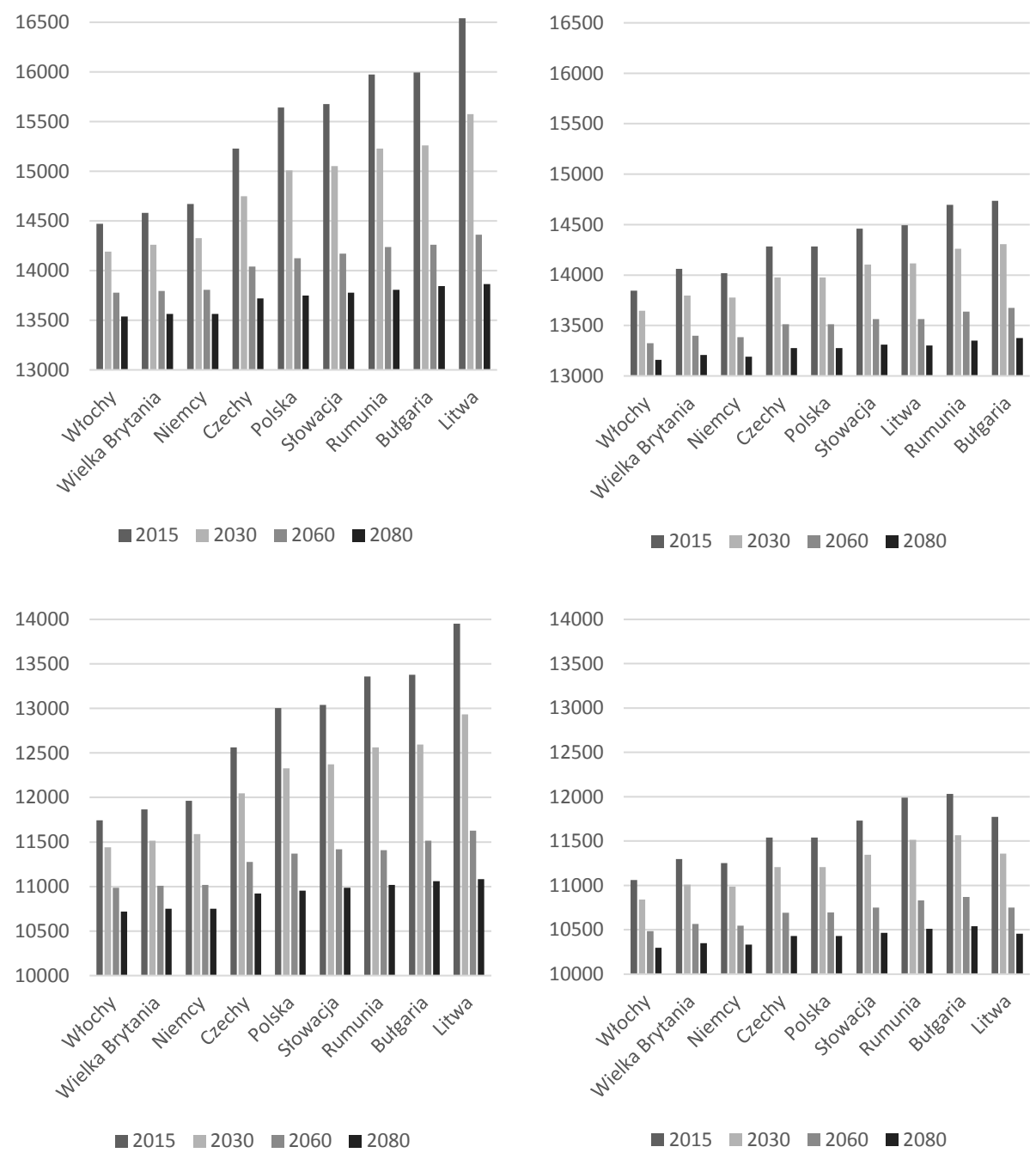

$1 \mathrm{~L}$ - wysokości kapitału na miesięczne świadczenia przy założeniu renty stałej dla 30-letniego mężczyzny

1P - wysokości kapitału na miesięczne świadczenia przy założeniu renty stałej dla 30-letniej kobiety $2 \mathrm{~L}$ - wysokości kapitału na miesięczne świadczenia przy założeniu renty rosnącej dla 30-letniego mężczyzny 2P - wysokości kapitału na miesięczne świadczenia przy założeniu renty rosnącej dla 30-letniej kobiety

Rysunek 3. Wysokość miesięcznego świadczenia, które można wypłacić z minimalnej sumy gwarancyjnej ubezpieczenia OC posiadaczy pojazdów mechanicznych 30-letniemu poszkodowanemu (w euro) Żródło: opracowanie własne na podstawie danych z Eurostatu [http://ec.europa.eu/eurostat/ data/database] oraz banku Centralnego [http://data.worldbank.org]. 
Zaprezentowana kalkulacja obrazuje, że wydłużające się trwanie życia winno zmusić ubezpieczycieli (oraz inne podmioty wypłacające świadczenia oparte na długości życia, np. ZUS) do podjęcia działań zapewniających im wyższe kapitały potrzebne do ich pokrywania. Jak wskazano w obliczanych przykładach dla Polski kapitał potrzebny na pokrycie takiej samej renty dla osoby urodzonej w 2015 r. i dla urodzonej 2080 r. różni się o kilkanaście procent.

Druga zaprezentowana kalkulacja wskazuje też na konieczność zwiększania minimalnych sum gwarancyjnych dla ubezpieczeń OC posiadaczy pojazdów mechanicznych celem zachowania takiego samego stopnia ochrony poszkodowanych. Naturalnym jej rozwinięciem może być też refleksja nt. kapitału emerytalnego, który winno się gromadzić. Jak widać, dla osób urodzonych później kapitał o tej samej wysokości nie będzie gwarantował wypłat o tej samej wysokości. Dla Polski jest to obniżenie miesięcznego świadczenia do poziomu około $90 \%$ dla osoby urodzonej w roku 2080 względem świadczenia dla urodzonej w roku 2015.

\section{Bibliografia}

Blake D., Boardman T., Cairns A. (2010), The case of longevity bonds, "Center for Retirement Research at Boston College", no. 10-10.

Jurek Ł. (2012), Ekonomia starzejącego się społeczeństwa, Difin, Warszawa.

Komisja Europejska (2015), The 2015 Ageing Report, „European Economy”, no. 3.

Kwiecień I., Jędrzychowska A. (2014), Renty z tytułu szkód na osobie - tendencje i wyzwania w ubezpieczeniach odpowiedzialności cywilnej, [w:] Współczesne wyzwania z bankowości i finansach , „Problemy Zarządzania”, vol. 12, nr 4(48), t. 1, Wydawnictwo naukowe WZ UW, Warszawa.

MacMinn R., Brockett P., Blakje D. (2006), Longevity risk and capital markets, „The Journal of Risk and Insurance", vol. 73, no. 4, http://onlinelibrary.wiley.com/doi/10.1111/ j.1539-6975.2006.00188.x/full (dostęp: 16.01.2016).

Ngai A., Sherris M. (2011), Longevity risk management for life and variable annuities: The effectiveness of static hedging using longevity bonds ad derivatives, "Insurance: Mathematics and Economics", vol. 49, no. 1.

Trzpiot G. (2015a), Wybrane determinanty ryzyka długowieczności, ,'Studia Ekonomiczne. Zeszyty Naukowe UE w Katowicach", nr 223.

Trzpiot G. (2015b), Finansowe implikacje ryzyka długowieczności, „Studia Ekonomiczne. Zeszyty Naukowe UE w Katowicach", nr 241. 


\section{WYDŁUŻANIE TRWANIA ŻYCIA A PŁATNOŚCI RENTOWE Z UBEZPIECZEŃ OC}

Artykuł poświęcony jest ryzyku długowieczności, a w szczególności wskazaniu jego wpływu na świadczenia rentowe wypłacane z ubezpieczeń odpowiedzialności cywilnej. Zjawisko wydłużania się życia jest obserwowane w ostatnich latach w krajach europejskich. Ma ono wpływ na wiele obszarów życia i gospodarki, a także dla finansów i ubezpieczeń. Zwiększający się udział osób starszych w społeczeństwie jest istotnym wyzwaniem tak dla państw, jak i instytucji finansowych, głównie banków, zakładów ubezpieczeń oraz funduszy hipotecznych. Podmioty te będą musiały uwzględniać wydłużanie się trwania życia w zarządzaniu systemami emerytalnymi oraz portfelem oferowanych produktów, w szczególności tych, które narażone są właśnie na ryzyko długowieczności z uwagi na płatności okresowe bez zakreślenia horyzontu czasowego. Przy niektórych produktach, jak odwrócona hipoteka czy renty z zamkniętym okresem płatności ryzyko właściwej oceny okresu wypłaty ciążyć będzie na beneficjencie. Świadome faktu wydłużania się życia muszą też osoby gromadzące swój kapitał emerytalny. W artykule autorki wskazują dane obrazujące zjawisko wydłużania trwania życia oraz ilustrują problem wpływu zjawiska w obszarze ubezpieczeń poprzez weryfikację znaczenia tego czynnika w kształtowaniu płatności rentowych w ubezpieczeniach OC. Ilustracje liczbowe ukazują wpływ wydłużania się dalszego trwania życia na obecną wartość kapitału rentowego oraz tego, jak przy utrzymaniu stałej wysokości minimalnej sumy gwarancyjnej obniża się wysokość kapitału na poczet miesięcznego świadczenia.

Słowa kluczowe: długowieczność, świadczenia rentowe, ubezpieczenia odpowiedzialności cywilnej.

\section{LONGEVITY AND ANNUITIES PAID FROM THE LIABILITY INSURANCE}

The article discusses the longevity risk, in particular the indication of annuities paid under liability insurance. Extending life is observed in recent years in European countries. It has an impact on many areas of life and economy, as well as finance and insurance. The increasing number of older people in society is a major challenge both for the states and financial institutions, mainly banks, insurance companies and mortgage funds. These entities will also have to consider lengthening life expectancy in the management of pension systems and the portfolio of products offered, in particular those exposed to longevity risk just because of the payments without final time horizon. The risk of lengthening of life is also important for future retirees and affects size of adequate pension capital. In the article the authors picture the phenomenon of lengthening life time and next illustrate the impact on annuities paid for bodily injuries under liability insurance.

Keywords: longevity, annuities, liability insurance. 